\title{
Sequential deposition method fabricating carbon- based fully-inorganic perovskite solar cells
}

\author{
Xihong Ding ${ }^{1}$, Yingke Ren ${ }^{1}$, Yahan $\mathrm{Wu}^{1}$, Yafeng $\mathrm{Xu}^{2}$, Jun $\mathrm{Zhu}^{2,3^{*}}$, Tasawar Hayat ${ }^{4,5}$, Ahmed Alsaedi ${ }^{4}$, \\ Zhaoqian $\mathrm{Li}^{2}$, Yang Huang ${ }^{2}$ and Songyuan Dai ${ }^{1,2^{*}}$
}

\begin{abstract}
Hybrid organic-inorganic halide perovskite material has been considered as a potential candidate for various optoelectronic applications. However, their high sensitivity to the environment hampers the actual application. Hence the technology replacing the organic part of the hybrid solar cells needs to be developed. Herein, we fabricated fullyinorganic carbon-based perovskite $\mathrm{CsPbBr}_{3}$ solar cells via a sequential deposition method with a power conversion efficiency of $2.53 \%$ and long-time stability over $20 \mathrm{~d}$ under ambient air conditions without any encapsulation. An evolution process from tetragonal $\mathrm{CsPb}_{2} \mathrm{Br}_{5}$ to $\mathrm{CsPb}_{2} \mathrm{Br}_{5}-\mathrm{CsPbBr}_{3}$ composites to quasi-cubic $\mathrm{CsPbBr}_{3}$ was found, which was investigated by scanning electron microscopy, $\mathrm{X}$-ray diffraction spectra, UV-vis absorption spectra and Fourier transform infrared spectroscopy. Detailed evolution process was studied to learn more information about the formation process before $10 \mathrm{~min}$. Our results are helpful to the development of inorganic perovskite solar cells and the $\mathrm{CsPb}_{2} \mathrm{Br}_{5}$ based optoelectronic devices.
\end{abstract}

Keywords: perovskite solar cell, phase transition, carbon cathode

\section{INTRODUCTION}

In the past several years, hybrid organic-inorganic halide perovskites with the common formulation $A B X_{3}$ (where $A$ is an organic cation, $B$ is commonly $\mathrm{Pb}^{2+}$ and $X$ is a halide) have undergone breathtaking progress in power conversion efficiency (PCE) from nascent 3.8\% [1] to a striking record of $22.1 \%$ [2]. Hybrid organic-inorganic halide perovskites have been verified to be in possession of many excellent properties, such as long electron/hole diffusion length [3], remarkable sunlight absorption [4], easy and low-cost fabrication process [5], etc., which make them an ideal candidate for lots of applications in photodetectors [6], light-emitting devices [7], semiconductor lasers [8], and solar cells [9-11].

However, the actual application of hybrid perovskites is hindered because of their strong sensitivity to ultraviolet (UV) light [12], heat [13], and moisture [14,15]. Fortunately, inorganic cesium lead halides, $\mathrm{CsPb} X_{3}(X=\mathrm{Cl}$, $\mathrm{Br}, \mathrm{I})$ show prominent compositional stability under thermal stress and remarkable photoelectric features with high electron mobility up to $\sim 1000 \mathrm{~cm}^{2} \mathrm{~V}^{-1} \mathrm{~s}^{-1}$ [16]. In 2015, the first inorganic $\mathrm{CsPbr}_{3}$ perovskite solar cells (PSCs) were reported by Kulbak et al. [17], acquiring a PCE of about 5\%. More recently, Liao et al. [18] reported $\mathrm{CsPbX}$ nanowires stable solar cells with PCE of $1.21 \%$ and stability around $5500 \mathrm{~h}$. Liang et al. [19] reported carbon-based $\mathrm{CsPbBr}_{3}$ solar cells with a PCE of $6.7 \%$ and stability over three months in humid air (90\%-95\% relative humidity, $25^{\circ} \mathrm{C}$ ). As for $\mathrm{CsPbI}_{3}$, undesired orthorhombic phase was formed with a low PCE of $0.09 \%$ due to its poor phase stability to moisture [20]. $\mathrm{CsPb}_{2} \mathrm{Br}_{5}$ is another important material for optoelectronic applications. The advantages of $\mathrm{CsPb}_{2} \mathrm{Br}_{5}$ used in optoelectronic devices lie in the intrinsic sandwiched structure and physical properties from the structure. In the tetragonal $\mathrm{CsPb}_{2} \mathrm{Br}_{5}$ structure, one layer of $\mathrm{Cs}$ ions is sandwiched between two layers of $\mathrm{Pb}-\mathrm{Br}$ coordination polyhedrons [21]. Now the applications of $\mathrm{CsPb}_{2} \mathrm{Br}_{5}$ include laser and

\footnotetext{
${ }^{1}$ Beijing Key Laboratory of Novel Thin-Film Solar Cells, North China Electric Power University, Beijing 102206, China

${ }^{2}$ Key Laboratory of Photovoltaic and Energy Conservation Materials, Hefei Institutes of Physical Science, Chinese Academy of Sciences, Hefei 230031, China

${ }^{3}$ Key Lab of Special Display Technology, Ministry of Education, National Engineering Lab of Special Display Technology, State Key Lab of Advanced Display Technology, Academy of Opto-Electronic Technology, Hefei University of Technology, Hefei 230009, China

${ }^{4}$ NAAM Research Group, Department of Mathematics, Faculty of Science, King Abdulaziz University, Jeddah 21589, Saudi Arabia

${ }^{5}$ Department of Mathematics, Quaid-I-Azam University, Islamabad 44000, Pakistan

* Corresponding authors (emails: zhujzhu@gmail.com (Zhu J); sydai@ipp.ac.cn (Dai S))
} 
a

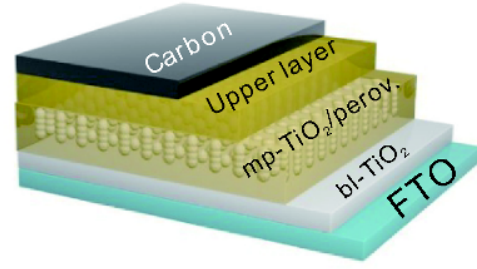

c

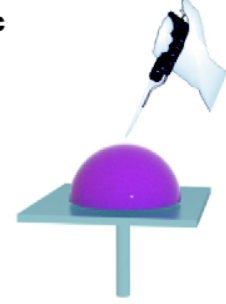

$\mathrm{PbBr}_{2}$ DMF/DMSO solution spreading

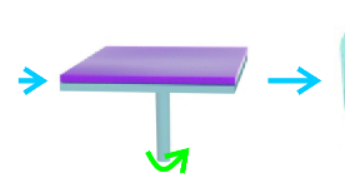

Spinning
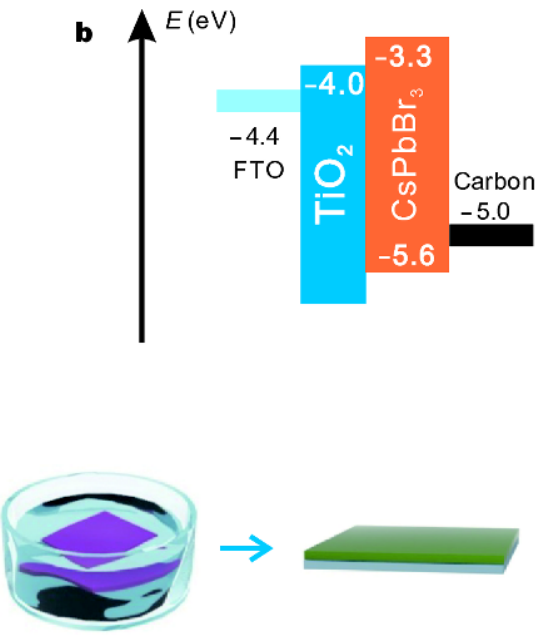

After rinsed by IPA, heated at $250^{\circ} \mathrm{C}$ for $5 \mathrm{~min}$

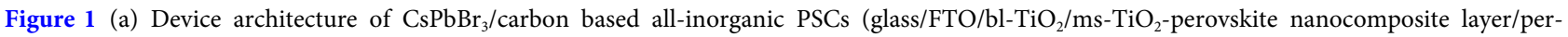
ovskite upper layer/carbon); (b) energy level diagram of $\mathrm{CsPbr}_{3} /$ carbon based all-inorganic PSCs; (c) scheme view of fabrication process of the perovskite film using sequential deposition method.

light-emitting devices [22-24]. Compared with the perovskite $\mathrm{CsPbBr}$, the available research on the structure and physical properties of the tetragonal $\mathrm{CsPb}_{2} \mathrm{Br}_{5}$ is not very sufficient and many great blanks need to be filled [21]. Our results offer a facile way to synthesize $\mathrm{CsPb}_{2} \mathrm{Br}_{5}$, which could enlighten other researchers to develop and design more applications of $\mathrm{CsPb}_{2} \mathrm{Br}_{5}$. At the same time, we use sequential deposition method obtaining $\mathrm{CsPbBr}_{3}$ films using carbon as hole-transporting material and photocathode, achieving a PCE of $2.53 \%$ with long-term stability. Scanning electron microscopy (SEM), X-ray diffraction spectra (XRD), Fourier transform infrared spectroscopy (FT-IR) and UV-vis absorption spectra were used to investigate $\mathrm{CsPb}_{2} \mathrm{Br}_{5}, \mathrm{CsPbBr}_{3}$ and the transition from $\mathrm{CsPb}_{2} \mathrm{Br}_{5}$ to $\mathrm{CsPbBr}$. Our results are helpful to the development of fully-inorganic $\mathrm{CsPbBr}_{3}$ solar cells and $\mathrm{CsPb}_{2} \mathrm{Br}_{5}$ based optoelectronic device.

\section{EXPERIMENTAL SECTION}

\section{Materials}

F-doped $\mathrm{SnO}_{2}$ glass (FTO, $15 \Omega /$ square) was purchased from Pilkington TEC. Lead bromide ( $\left.\mathrm{PbBr}_{2}, \geq 98 \%\right), N, N$ dimethylformamide (DMF) and dimethyl sulphoxide (DMSO) were obtained from Aldrich. Cesium bromide $\left(\mathrm{CsBr},>99 \%\right.$ ) was purchased from TCI. $\mathrm{TiO}_{2}$ (particle size: about $30 \mathrm{~nm}$, crystalline phase: anatase) was purchased from Dyesol. Methanol (AR) and isopropanol (IPA, 99.7\%) were obtained from Sinopharm Chemical
Reagent Co., Ltd. All chemicals were straightly used without further purification.

\section{Device fabrication}

Etched FTO-coated glass substrates were cleaned by ultrasonication in deionized water followed by washed with acetone and ethanol. These substrates were exposed to UV-ozone for $15 \mathrm{~min}$. A $\sim 60 \mathrm{~nm}$-thick $\mathrm{TiO}_{2}$ blocking layer was deposited on the cleaned FTO by spray pyrolysis, using $\mathrm{N}_{2}$ as carrier gas, at $430^{\circ} \mathrm{C}$ from a precursor solution of $0.6 \mathrm{~mL}$ of titanium diisopropoxide and $0.4 \mathrm{~mL}$ of bis(acetylacetonate) in $7 \mathrm{~mL}$ of anhydrous isopropanol. A mesoporous $\mathrm{TiO}_{2}$ layer (particle size: about $30 \mathrm{~nm}$, crystalline phase: anatase, diluted to $w / w=1 / 5.5$ in ethanol) about 100-150 nm thickness film was deposited by spin coating at $5000 \mathrm{rpm}$ for $30 \mathrm{~s}$ onto the blocking layer (bl) $-\mathrm{TiO}_{2} / \mathrm{FTO}$ substrates. After spin coating, the substrate was immediately dried on a hotplate at $105^{\circ} \mathrm{C}$, and the substrates were then heated at $500^{\circ} \mathrm{C}$ to remove organic components followed by baking for $2 \mathrm{~h}$. Then, as illustrated in Fig. 1c, firstly, $1.4 \mathrm{~mol} \mathrm{~L} \mathrm{PbBr}_{2} \mathrm{DMF} /$ DMSO solution (DMF/DMSO $v / v=9 / 1$ ) was spread over the entire surface of the substrate. Secondly, the spincoater was accelerated to the desired rotational speed at $2000 \mathrm{rpm}$ for $30 \mathrm{~s}$. Thirdly, the as-prepared $\mathrm{PbBr}_{2}$ films were dipped into $15 \mathrm{mg} \mathrm{mL}^{-1} \mathrm{CsBr}$ methanol solution for various time. Finally, the perovskite films were rinsed by IPA and heated at $250^{\circ} \mathrm{C}$ for $5 \mathrm{~min}$. Then, the carbon paste was deposited on the perovskite films by screen 

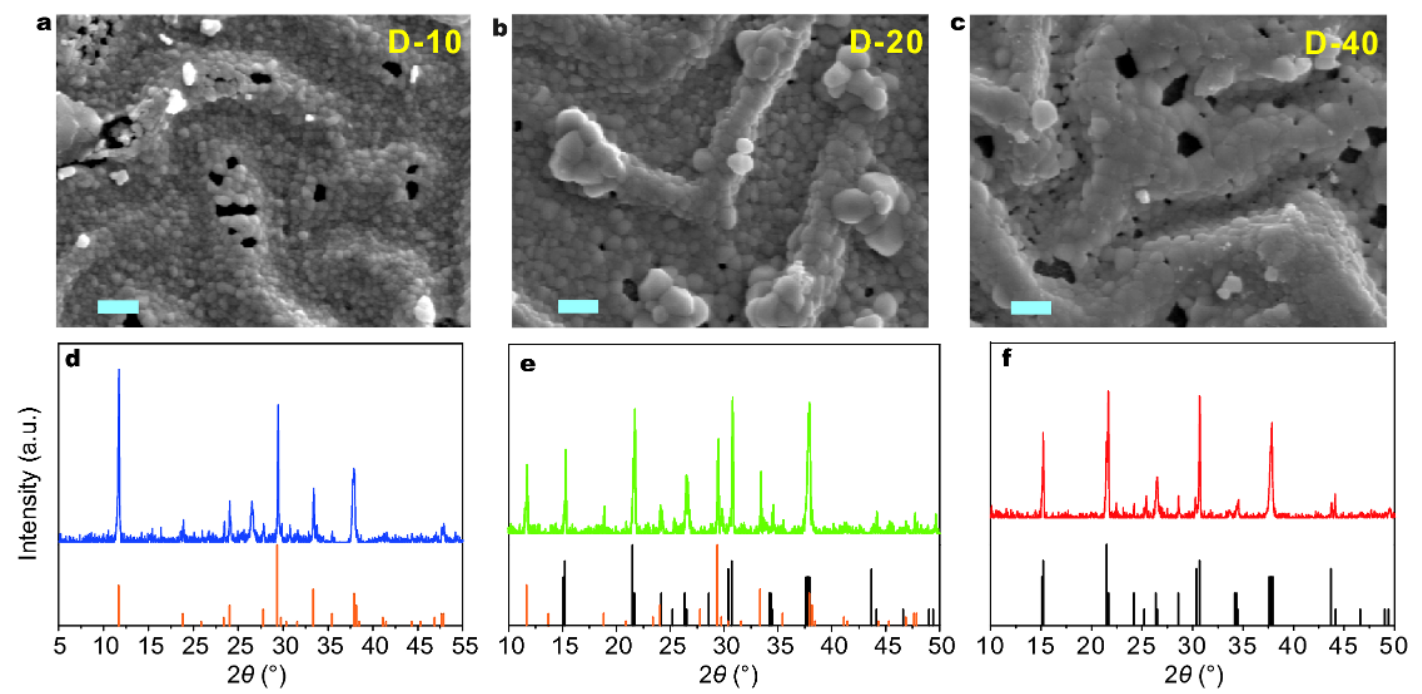

Figure 2 SEM Images of inorganic active layer: (a) D-10; (b) D-20; (c) D-40; the scale bar is $1 \mu \mathrm{m}$ and XRD patterns of D-10 (d), D-20 (e), D-40 (f) with standard XRD patterns, orange line: tetragonal $\mathrm{CsPb}_{2} \mathrm{Br}_{5}$, JCPDS No. 00-025-0211; black line: monoclinic CsPbBr 3 , JCPDS No. 00-018-0364.

printing followed by heating at $70^{\circ} \mathrm{C}$ for $1 \mathrm{~h}$.

\section{Characterization}

Film morphology was investigated by using a high-resolution scanning electron microscope (S4800, Hitachi) equipped with a Schottky Field Emission gun. The X-ray diffraction spectra were recorded on an X'pert PRO X-ray diffractometer. The data were gathered at room temperature in the $2 \theta$ range $5^{\circ}-50^{\circ}$. The $J-V$ curves were measured using a solar simulator (Newport, Oriel Class A, 91195A) with a source meter (Keithley 2420) at $100 \mathrm{~mA} \mathrm{~cm}^{-2}$ illumination AM $1.5 \mathrm{G}$ and a calibrated Sireference cell. The $J-V$ curves for all devices were measured by masking the active area with a black mask $0.09 \mathrm{~cm}^{2}$. The applied bias voltage was from 1.2 to $-0.1 \mathrm{~V}$ and the scan rate was $50 \mathrm{mV} \mathrm{s}^{-1}$. UV-vis absorption spectra were recorded on a UV-vis spectrometer (Hitachi U-3300). Fourier transform infrared spectroscopy (FT-IR, ThermoFisher IS50R, USA) was used to collect the spectral data for various solution in the range of $4000-500 \mathrm{~cm}^{-1}$.

\section{RESULTS AND DISCUSSION}

\section{Structure and morphology characterization}

Fig. 1 presents the device architecture, energy level diagram as well as scheme of films fabrication process. The cell structure (Fig. 1a) exhibits a bilayer structure making up of mesoporous and planar structures, which is effective for adequately absorbing light and gathering charges.
Atop the mesoporous (mp)- $\mathrm{TiO}_{2}$ layer lies a uniform perovskite active layer. Upward the perovskite active layer lies a layer of carbon working as bi-functional films for both electron blocking and hole collecting for the reason of its fit work function $(-5.0 \mathrm{eV})$ close to that of gold $(-5.1 \mathrm{eV})$. Fig. $1 \mathrm{~b}$ exhibits the energy band diagram of FTO, $\mathrm{TiO}_{2}, \mathrm{CsPbBr}_{3}$ and carbon layers, uncovering the smooth electron injection from $\mathrm{Cs} \mathrm{PbBr}_{3}$ conduction band to $\mathrm{TiO}_{2}$ conduction band and hole extraction from $\mathrm{CsPbBr}_{3}$ valence band to carbon photocathode. Fig. 1c shows the perovskite films fabrication process, in which the as-prepared $\mathrm{PbBr}_{2}$ films was dipped in $15 \mathrm{mg} \mathrm{mL}^{-1}$ $\mathrm{CsBr}$ methanol solution for 10 (D-10), 20 (D-20) and $40 \min (\mathrm{D}-40)$.

The surface morphology evolution of the inorganic active layer based on different dipping time was investigated by SEM (Fig. 2a-c). The films dipped in $\mathrm{CsBr}$ methanol solution for $10 \mathrm{~min}$ (D-10) exhibit relatively low surface coverage and small grain size (the average grain size is $216 \mathrm{~nm}$ calculated by software Nanomeasurer with 30 sample points.) The D-20 film is relatively more uniform with average grain size of $275 \mathrm{~nm}$. For the D-40 film, the average grain size becomes larger up to $391 \mathrm{~nm}$. Our results show that longer dipping time is beneficial for better performance of the $\mathrm{Cs} \mathrm{PbBr}_{3}$ PSCs. It is worthy to note that all the three kinds of films have lots of fluctuation, which is detrimental to electron and hole transfer. The cause of the fluctuation is unclear and need to be further studied. Fig. S1 (Supplementary information) illustrates the carbon photocathode, which shows it com- 
prised carbon nanoparticles with average diameter of $\sim 100 \mathrm{~nm}$.

The XRD measurement was conducted to investigate the crystal phase evolution of these samples. As depicted in Fig. 2d, the XRD pattern of D-10 films could match well with standard patterns of tetragonal phase $\mathrm{CsPb}_{2} \mathrm{Br}_{5}$ (JCPDS No. 00-025-0211), whose lattice parameters are $a=b=8.483 \AA, c=15.250 \AA, \alpha=\beta=\gamma=90.000^{\circ}$. Along with the prolonging of dipping time, as shown in Fig. $2 \mathrm{e}$, a different material and phase emerged in the D-20 films, which is ascribed to monoclinic phase $\mathrm{CsPbBr}_{3}$ (JCPDS No. 00-018-0364), with lattice parameters $a=b=5.827 \AA$, $c$ $=5.891 \AA, \alpha=\beta=90.000^{\circ}, \gamma=89.650^{\circ}$. It is quite similar as cubic phase with slight difference of $c$ and $\gamma$, so we call this structure as quasi-cubic phase $\mathrm{CsPbBr}_{3}$. In the D-20 films, the XRD peaks belong to two kinds of materials (tetragonal $\mathrm{CsPb}_{2} \mathrm{Br}_{5}$ and quasi-cubic $\mathrm{CsPbBr}$ ), indicating the material and phase evolution is in progress and the $\mathrm{CsPb}_{2} \mathrm{Br}_{5}$ has not completely evolved to $\mathrm{CsPbBr}$. However, when we turn to the D-40 films, as illustrated in Fig. 2f, all the $\mathrm{CsPb}_{2} \mathrm{Br}_{5}$ converts to $\mathrm{CsPbBr}$. It is worthy to note that no peak of $\mathrm{PbBr}_{2}$ could be found, indicating the sufficient reaction of $\mathrm{PbBr}_{2}$ and $\mathrm{CsBr}$ with no $\mathrm{PbBr}_{2}$ residual remained in all the three kinds of films. Fig. S2 shows absorbance of the D-10, D-20 and D-40 films. The light absorption peaks of D-20 and D-40 films are shorter than $\sim 540 \mathrm{~nm}$ and the absorption peak of D-10 films is shorter than $\sim 375 \mathrm{~nm}$, which suggests tetragonal $\mathrm{CsPb}_{2} \mathrm{Br}_{5}$ was not suitable for photovoltaic applications.

To learn more information about the formation process at the interface of $\mathrm{PbBr}_{2}$ films and the $\mathrm{CsBr}$ methanol solution before $10 \mathrm{~min}$, we investigated the as-prepared $\mathrm{PbBr}_{2}$ films dipped in the $15 \mathrm{mg} \mathrm{mL}^{-1} \mathrm{CsBr}$ methanol solution for 1 (D-1), 2 (D-2) and $5 \mathrm{~min}$ (D-5). XRD measurement and UV-vis spectra were used to further investigate $\mathrm{CsPb}_{2} \mathrm{Br}_{5}$. As depicted in Fig. 3a, the XRD patterns of D-1, D-2 and D-5 have slight difference in the intensity, while all matching well with the standard XRD pattern ( $\mathrm{CsPb}_{2} \mathrm{Br}_{5}$ JCPDS No. 00-025-0211), indicating that even early at $1 \mathrm{~min}$, the tetragonal $\mathrm{CsPb}_{2} \mathrm{Br}_{5}$ was formed at the interface. It is worthy to note that the full width at half maxima (FWHM) of XRD patterns of D-1, D-2 and D-5 films are wider than that of D-10, showing smaller grainsize compared with the D-10 films according to Debye-Scherrer formula. As presented in Fig. S3, the light absorption peaks of these films are shorter than $\sim 375 \mathrm{~nm}$.

Combining the previous reports $[21,22,25]$ and the fact that no $\mathrm{PbBr}_{2}$ residual could be found in D-10 films, we hypothesize the reaction route according to the equation:
$\mathrm{CsBr}+2 \mathrm{PbBr}_{2} \rightarrow \mathrm{CsPb}_{2} \mathrm{Br}_{5}$. Then, $\mathrm{CsPb}_{2} \mathrm{Br}_{5}$ continues to react with $\mathrm{CsBr}$ in methonal according to the equation: $\mathrm{CsPb}_{2} \mathrm{Br}_{5}+\mathrm{CsBr} \rightarrow 2 \mathrm{CsPbBr}_{3}$. In the first step, the effect of the $\mathrm{PbBr}_{2} \cdot \mathrm{DMF}$ adduct is considered to be important for the formation of $\mathrm{CsPb}_{2} \mathrm{Br}_{5}$. Without the existence of the adduct, the reaction process should be different $[19,26]$. FT-IR was conducted to confirm the existence of the adduct. As depicted in Fig. 3b, the stretching vibrations of $\mathrm{C}=\mathrm{O}$ in DMF and DMSO $(v / v=9: 1)$ mixed solution (T-1 solution) were located at $1670 \mathrm{~cm}^{-1}$. When $513.8 \mathrm{mg}$ $\mathrm{PbBr}_{2}$ was added to $1 \mathrm{~mL} \mathrm{~T}-1$ solution (T-2 solution), some of the vibrations of $\mathrm{C}=\mathrm{O}$ shifted to 1638 from $1670 \mathrm{~cm}^{-1}$, which could prove the existence of $\mathrm{PbBr}_{2} \cdot \mathrm{DMF}$ adduct.

\section{Photovoltaic performance}

The photovoltaic application of perovskite has recently become a hotspot. In consideration of this, we fabricated the PSCs based on D-10, D-20, D-40 films. Table 1 summarizes the typical photovoltaic properties of the three kinds of solar cells. Unfortunately, the device based on D-10 films did not perform photovoltaic properties because of its broad band gap. However, we propose a new strategy to synthesis $\mathrm{CsPb}_{2} \mathrm{Br}_{5}$ here, which will help other researchers to expand its application in other fields. The devices based on D-20 films show a relatively low open circuit voltage $\left(V_{\text {oc }}\right)$, short current density $\left(J_{\text {sc }}\right)$, PCE, and fill factor (FF) comparing with the devices based on $\mathrm{D}-40$ films because of the existence of $\mathrm{CsPb}_{2} \mathrm{Br}_{5}$. The best cell based on D-40 films, as depicted in Fig. 3c, yielded a $J_{\text {sc }}$ of $3.52 \mathrm{~mA} \mathrm{~cm}^{-2}$, a $V_{\text {oc }}$ of $1.15 \mathrm{~V}$, an FF of 0.624 and a PCE of $2.53 \%$. Fig. $3 \mathrm{~d}$ presents the cross-sectional SEM image of the device based on D-40 films, signifying a structure making up of FTO, $60 \mathrm{~nm}$-thick bl- $\mathrm{TiO}_{2}, 200$ nm-thick meso- $\mathrm{TiO}_{2}$ /perov., $650 \mathrm{~nm}$-thick upper layer and carbon photocathode.

\section{Stability of devices}

The stability of solar cells is of fundamental importance to the commercialization process. Stability is still a challenge for the hybrid PSCs [27]. Herein the stability test of the devices based on D-40 films were conducted under ambient air without any encapsulation. Fig. 3e illustrates normalized stability curves of the device based on D-40 films, which shows that the PSCs were stable after $20 \mathrm{~d}$. Prominent stability will be beneficial to the commercial application process.

\section{CONCLUSION}

In summary, we proposed a simple sequential deposition 

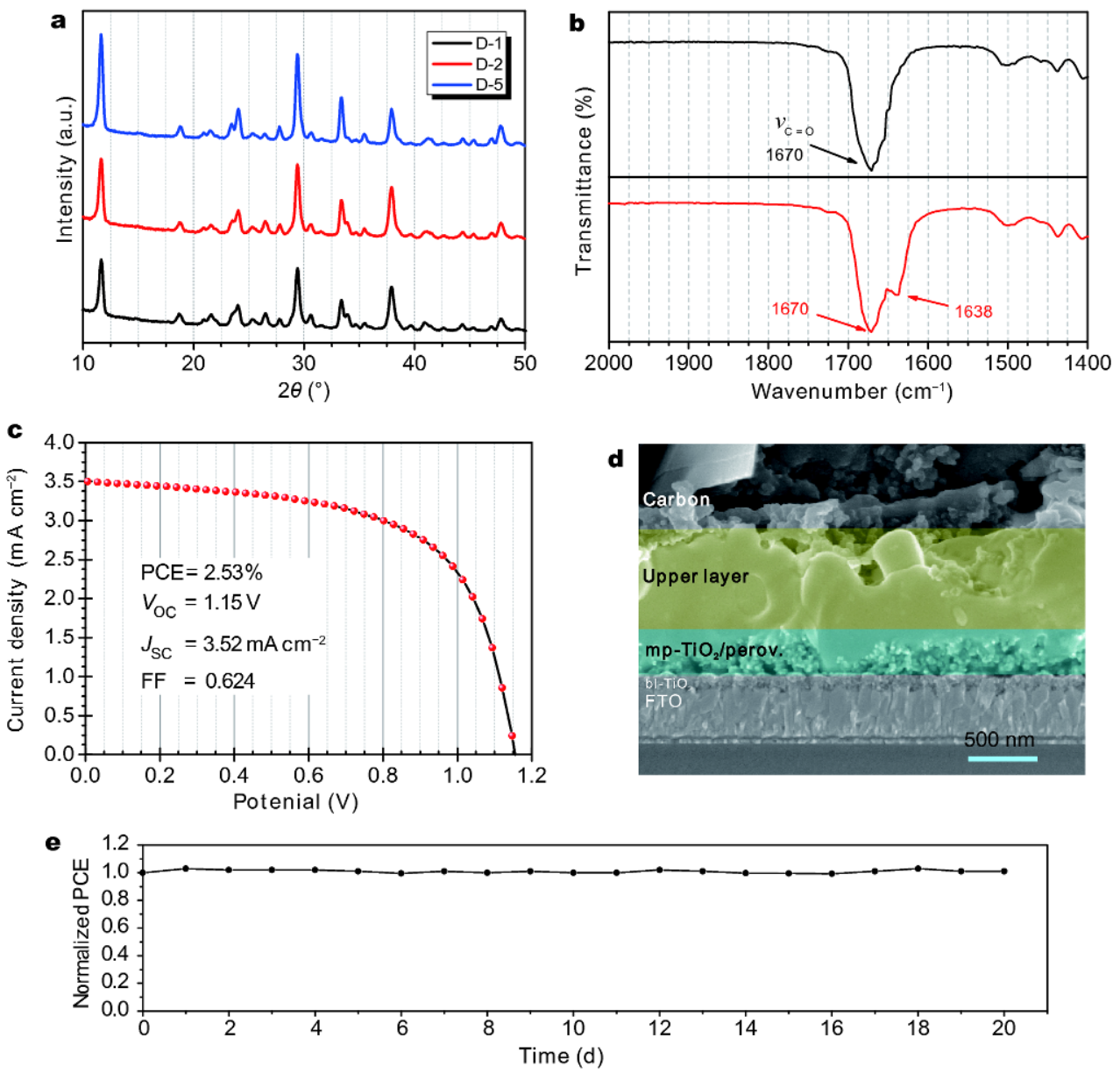

Figure 3 (a) XRD patterns of D-1, D-2, D-5 films; (b) FT-IR of T-1 solution (black line) and T-2 solution (red line); (c) champion cell's $J$ - $V$ characteristics of the PSC devices based on D-40 films; (d) cross-sectional SEM image of a full cell based on D- 40 films, the scale bar is $500 \mathrm{~nm}$; (e) normalized PCE of the device based on D-40 films.

Table 1 Typical device performance of PSCs

\begin{tabular}{ccccc}
\hline & $J_{\mathrm{sc}}\left(\mathrm{mA} \mathrm{cm}^{-2}\right)$ & $V_{\mathrm{oc}}(\mathrm{V})$ & PCE $(\%)$ & FF \\
\hline D-10 & - & - & - & - \\
D-20 & 1.89 & 0.83 & 0.82 & 0.52 \\
D-40 & 3.25 & 1.10 & 2.18 & 0.61 \\
\hline
\end{tabular}

method to fabricate fully-inorganic PSCs using carbon as hole-transporting material and photocathode. A material and phase evolution process from tetragonal $\mathrm{CsPb}_{2} \mathrm{Br}_{5}$ to quasi-cubic $\mathrm{CsPbBr}$ was found and characterized. SEM, XRD patterns, UV-vis spectra and FT-IR spectra were used to investigate the evolution process. We proposed a hypothesis to explain the evolution process. The best cell based on quasi-cubic $\mathrm{CsPbBr}_{3}$ films presented a PCE of $2.53 \%$ with long stability over $20 \mathrm{~d}$ under ambient air conditions without any encapsulation. Our results are helpful to the development of $\mathrm{CsPbBr}_{3}$ based PSCs. In addition, the facile way to synthesize $\mathrm{CsPb}_{2} \mathrm{Br}_{5}$ could enlighten other researchers to develop and design more applications of it.

Received 7 July 2017; accepted 12 September 2017; published online 27 October 2017

1 Kojima A, Teshima K, Shirai Y, et al. Organometal halide perovskites as visible-light sensitizers for photovoltaic cells. J Am Chem Soc, 2009, 131: 6050-6051

2 http://www.nrel.gov/ncpv/images/efficiency_chart.pn. 2017.7.5

3 Dong Q, Fang Y, Shao Y, et al. Electron-hole diffusion lengths $>175$ $\mu \mathrm{m}$ in solution-grown $\mathrm{CH}_{3} \mathrm{NH}_{3} \mathrm{PbI}_{3}$ single crystals. Science, 2015, 347: 967-970

4 Ren Y, Duan B, Xu Y, et al. New insight into solvent engineering technology from evolution of intermediates via one-step spincoating approach. Sci China Mater, 2017, 60: 392-398

5 Lee JW, Kim HS, Park NG. Lewis acid-base adduct approach for high efficiency perovskite solar cells. Acc Chem Res, 2016, 49: 311319 
6 Tan ZK, Moghaddam RS, Lai ML, et al. Bright light-emitting diodes based on organometal halide perovskite. Nat Nanotech, 2014, 9: 687-692

7 Wang Z, Cheng T, Wang F, et al. Morphology engineering for high-performance and multicolored perovskite light-emitting diodes with simple device structures. Small, 2016, 12: 4412-4420

8 Xing G, Mathews N, Lim SS, et al. Low-temperature solutionprocessed wavelength-tunable perovskites for lasing. Nat Mater, 2014, 13: 476-480

9 Seo J, Noh JH, Seok SI. Rational strategies for efficient perovskite solar cells. Acc Chem Res, 2016, 49: 562-572

10 Li ZQ, Que YP, Mo LE, et al. One-pot synthesis of mesoporous $\mathrm{TiO}_{2}$ micropheres and its application for high-efficiency dye-sensitized solar cells. ACS Appl Mater Interfaces, 2015, 7: 1092810934

11 Li ZQ, Chen WC, Guo FL, et al. Mesoporous $\mathrm{TiO}_{2}$ yolk-shell microspheres for dye-sensitized solar cells with a high efficiency exceeding 11\%. Sci Rep, 2015, 5: 14178

12 Leijtens T, Eperon GE, Pathak S, et al. Overcoming ultraviolet light instability of sensitized $\mathrm{TiO}_{2}$ with meso-superstructured organometal tri-halide perovskite solar cells. Nat Commun, 2013, 4: 2885

13 Conings B, Drijkoningen J, Gauquelin N, et al. Intrinsic thermal instability of methylammonium lead trihalide perovskite. Adv Energ Mater, 2015, 5: 1500477

14 Manser JS, Saidaminov MI, Christians JA, et al. Making and breaking of lead halide perovskites. Acc Chem Res, 2016, 49: 330338

15 Liu X, Kong F, Cheng T, et al. Tetraphenylmethane-arylamine hole-transporting materials for perovskite solar cells. ChemSusChem, 2017, 10: 968-975

16 Stoumpos CC, Malliakas CD, Peters JA, et al. Crystal growth of the perovskite semiconductor $\mathrm{CsPbBr}_{3}$ : a new material for high-energy radiation detection. Cryst Growth Des, 2013, 13: 2722-2727

17 Kulbak M, Cahen D, Hodes G. How important is the organic part of lead halide perovskite photovoltaic cells? Efficient $\mathrm{CsPbBr}_{3}$ cells. J Phys Chem Lett, 2015, 6: 2452-2456

18 Liao JF, Li WG, Rao HS, et al. Inorganic cesium lead halide CsPbX nanowires for long-term stable solar cells. Sci China Mater, 2017, 60: $285-294$

19 Liang J, Wang C, Wang Y, et al. All-inorganic perovskite solar cells. J Am Chem Soc, 2016, 138: 15829-15832

20 Ripolles TS, Nishinaka K, Ogomi Y, et al. Efficiency enhancement by changing perovskite crystal phase and adding a charge extraction interlayer in organic amine free-perovskite solar cells based on cesium. Sol Energ Mater Sol Cells, 2016, 144: 532-536
21 Li G, Wang $\mathrm{H}$, Zhu Z, et al. Shape and phase evolution from $\mathrm{CsPbBr} r_{3}$ perovskite nanocubes to tetragonal $\mathrm{CsPb}_{2} \mathrm{Br}_{5}$ nanosheets with an indirect bandgap. Chem Commun, 2016, 52: 11296-11299

22 Tang X, Hu Z, Yuan W, et al. Perovskite $\mathrm{CsPb}_{2} \mathrm{Br}_{5}$ microplate laser with enhanced stability and tunable properties. Adv Opt Mater, 2017, 5: 1600788

23 Wang $\mathrm{KH}, \mathrm{Wu} \mathrm{L}$, Li L, et al. Large-scale synthesis of highly luminescent perovskite-related $\mathrm{CsPb}_{2} \mathrm{Br}_{5}$ nanoplatelets and their fast anion exchange. Angew Chem Int Ed, 2016, 55: 8328-8332

24 Zhang X, Xu B, Zhang J, et al. All-inorganic perovskite nanocrystals for high-efficiency light emitting diodes: dual-phase $\mathrm{CsPbBr}_{3}-\mathrm{CsPb}_{2} \mathrm{Br}_{5}$ composites. Adv Funct Mater, 2016, 26: 45954600

25 Dastidar S, Egger DA, Tan LZ, et al. High chloride doping levels stabilize the perovskite phase of cesium lead iodide. Nano Lett, 2016, 16: 3563-3570

26 Hoffman JB, Schleper AL, Kamat PV. Transformation of sintered $\mathrm{CsPbBr}_{3}$ nanocrystals to cubic $\mathrm{CsPbI}_{3}$ and gradient $\mathrm{CsPbBr}_{x} \mathrm{I}_{3-x}$ through halide exchange. J Am Chem Soc, 2016, 138: 8603-8611

27 Chen H. Two-step sequential deposition of organometal halide perovskite for photovoltaic application. Adv Funct Mater, 2017, 27: 1605654

Acknowledgements This work was supported by the National Basic Research Program of China (2016YFA0202400 and 2015CB932200), the National Natural Science Foundation of China (21403247), Distinguished Youth Foundation of Anhui Province (1708085J09), the Fundamental Research Funds for the Central Universities (2017XS079) and the Major/Innovative Program of Development Foundation of Hefei Center for Physical Science and Technology (2016FXZY003)

Author contributions Ding X conducted the main experiments and wrote this manuscript. Zhu J directly guided this research including the designing, modifying and optimizing work related to this manuscript. Dai $S$ supervised the projects and carefully reviewed and modified this manuscript. Ren Y, Wu Y, Xu Y, Tasawar H, Ahmed A, Li Z, Huang Y provided help in the fabrication of devices and methods of characterization. All authors contributed to the general discussion about this work.

Conflict of interest The authors declare that they have no conflict of interest.

Supplementary information online version of the paper.
Supporting data are available in the 

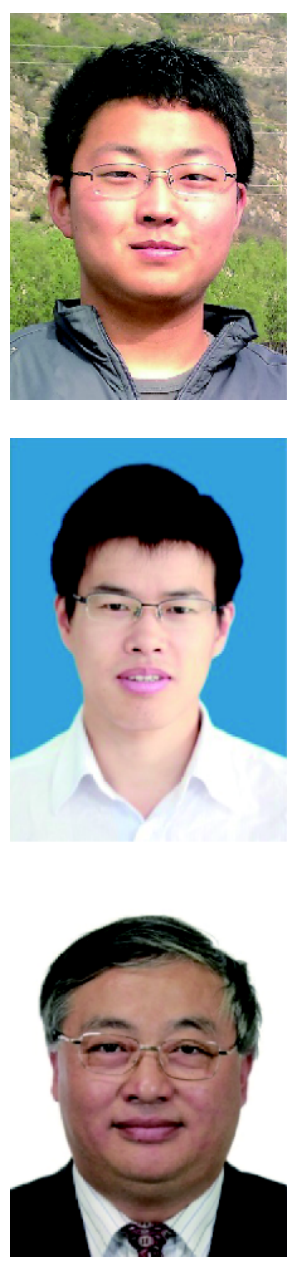

Xihong Ding gained his BSc degree from North China Electric Power University in 2015. He is now a PhD candidate of the North China Electric Power University under the supervision of Profs. Jun Zhu and Songyuan Dai. His research interests mainly focus on perovskite solar cells.
Jun Zhu received his PhD degree from University of Science and Technology of China in 2005. He joined Hefei Institutes of Physical Science, Chinese Academy of Sciences and was promoted to full professor in 2015. Now his research interests focus on the new generation solar cells, including quantum dot solar cells and perovskite solar cells.
Songyuan Dai is a professor and Dean of the School of Renewable Energy, North China Electric Power University. He obtained his BSc degree in physics from Anhui Normal University in 1987, and MSc and PhD degrees in plasma physics from the Institute of Plasma Physics, Chinese Academy of Sciences in 1991 and 2001. His research interests mainly focus on next-generation solar cells including dye-sensitized solar cells, quantum dot solar cells, perovskite solar cells, etc.

\section{连续沉积法制备碳电极无机钻钛矿太阳电池}

丁希宏 ${ }^{1}$, 任英科 ${ }^{1}$, 吴雅罕 ${ }^{1}$, 徐亚峰 ${ }^{2}$, 朱俊 $^{2,3^{*}}$, Tasawar Hayat ${ }^{4,5}$, Ahmed Alsaedi $^{4}$, 李兆乾 ${ }^{2}, \mathbf{M}^{\text {阳 }}{ }^{2}$, 戴松元 ${ }^{1,2^{*}}$

摘要 有机无机杂化钲钛矿是一种有潜力的光伏材料. 然而, 对于环境的高度敏感性限制了它的实际应用. 因此我们需要发展全无机钙钛 矿材料. 本文通过连续沉积法制备了效率达到 $2.53 \%$ 的碳电极 $\mathrm{CsPBr}_{3}$ 太阳电池, 并且它能够在无封装的情况下稳定 20 天. 在制备 $\mathrm{Cs} \mathrm{PbBr}_{3}$ 薄膜的过程中, 我们首次发现从 $\mathrm{CsPb}_{2} \mathrm{Br}_{5}$ 到 $\mathrm{CsPb}_{2} \mathrm{Br}_{5}-\mathrm{CsPbBr}_{3}$ 混合物到 $\mathrm{CsPbBr}_{3}$ 的转变. 该研究结果对于无机钙钛矿太阳电池的发展和 $\mathrm{CsPb}_{2} \mathrm{Br}_{5}$ 基光电器件具有帮助作用. 